DOI: $10.2478 / \mathrm{v} 10047-012-0005-5$

SOLID STATE PHYSICS

\title{
SURFACE MODIFICATION OF SB-SE THIN FILMS BY LASER IRRADIATION AND ETCHING
}

\author{
O. Shiman, V. Gerbreders, E. Sledevskis \\ Innovative Microscopy Center, Daugavpils University \\ 1 Parades Str.1, Daugavpils, LV-5400, LATVIA \\ e-mail: osimane@gmail.com; vjaceslavs.gerbreders@du.lv; sledevskis@inbox.lv
}

\begin{abstract}
The surfaces of $\mathrm{Sb}_{20} \mathrm{Se}_{80}$ and $\mathrm{Sb}_{40} \mathrm{Se}_{60}$ thin films were modified by exposure to laser light. To study the topology of these surfaces the scanning force microscopy was used. As a result, the surface of as-deposited/amorphous $\mathrm{Sb}_{\mathrm{x}} \mathrm{Se}_{100-\mathrm{x}}$ films appear to be flat, while the treated films exhibit three types of surface structure on the submicrometer scale. Changes in the surface characteristics as well as potential applications of selective etching of Sb-Se thin films are discussed.
\end{abstract}

Key words: amorphous and crystalline phases, chalcogenide thin films, etching process, laser treatment.

\section{INTRODUCTION}

Chalcogenide glasses are versatile semiconductor and dielectric functional materials, since, besides the basic photoconductivity and good IR optical transparency, they possess a number of well-known and widely investigated specific features - such as photo-induced change of optical parameters, electrical switching, optical non-linearity, etc.. These peculiarities, according to [1], are reviewed in a number of books and papers and applied in the electro-photography (e.g. Xeroxcopy machine), X-ray photoreceptors, ovonic switches, holographic gratings, waveguide sensors, optical switches, compact disc-rewritable (CD RW), etc..

Recently, considerable attention has been focused on glasses of $\mathrm{Se}-\mathrm{Sb}$ system, since these materials are extensively used owing to their electrical, optical, dielectric and thermal properties. $\mathrm{Sb}_{2} \mathrm{Se}_{3}$ thin films attract wide attention due to their good photovoltaic properties and high thermoelectric power (TEP), which makes possible diversified applications of optical and thermoelectric cooling devices. In turn, reports are available on the transport and optical properties of $\mathrm{Sb}-\mathrm{Se}[2,3]$ and $\mathrm{Sb}_{2} \mathrm{Se}_{3}[4]$ thin films. Some studies are concentrated on the photocrystallization [5], laser-induced amorphous-to-crystalline phase transition [6], thermocrystallization [7], crystallization by electron beam irradiation [8] in amorphous $\mathrm{Sb}-\mathrm{Se}$ thin films as well as $\mathrm{CW}$-laser induced spherulitic re-crystallization in $\mathrm{Sb}-\mathrm{Se}$ system [9]. In [10] the electrical and optical properties of a single $\mathrm{Sb}_{2} \mathrm{Se}_{3}$ nanorod are studied.

The mentioned materials can be used in the photolithography as highresolution registering media, which provide a resolution of several nanometers due to their amorphous structure [11] and are able to shape the surface relief after exposure and treatment. Apart from that, these materials can be used as data 
storage media. In view of the tendency to raise miniaturization of optic, electronic, optoelectronic and mechanical devices it is of importance to study variations in the material properties with size. In this context, creation of a micro- and nano-scaled thin film composition with predetermined surface morphology becomes especially promising and important.

The present work is an attempt to verify the laser-induced structural changes taking place on the surface of Sb-Se thin films - both of stoichiometric compound and with excessive selenium.

\section{EXPERIMENTAL}

Thin films were prepared by thermal evaporation from bulk glass samples of $\mathrm{Sb}_{\mathrm{x}} \mathrm{Se}_{100-\mathrm{x}}(\mathrm{x}=20,40)$ composition and in vacuum $10^{-5}$ Torr onto BK-7 glass substrates at room temperature (RT). The film thickness was controlled during evaporation by means of interference technique at the wavelength of $650 \mathrm{~nm}$ (see [6]); for the prepared films it was $\sim 100 \mathrm{~nm}$. The composition and structure of the deposited layers were analyzed using an INCA X-act detector, an EBSD (electron backscatter diffraction) system, and an X-ray diffractometer (SmartLab Rigaku).

The local crystallization of $\mathrm{Sb}_{\mathrm{x}} \mathrm{Se}_{100-\mathrm{x}}$ thin films was carried out using a HeNe laser $(\lambda=633 \mathrm{~nm}, 16 \mathrm{~mW}$ for $30 \mathrm{~min}$.)

For selective etching of optically crystallized/amorphous thin films an organics-based solution (e.g. amines) was used.

To study the modifications induced by light treatment of thin films the optical microscopy (a Leica TCS-SPE confocal laser-scanning microscope) and the scanning electron microscopy (SEM TESCAN VEGA) were employed. Changes in the surface morphology of samples were analyzed using the atomic force microscopy (AFM Veeco CP II).

\section{RESULTS}

The deposited samples were amorphous, with a rather smooth homogeneous surface (Fig. 1).

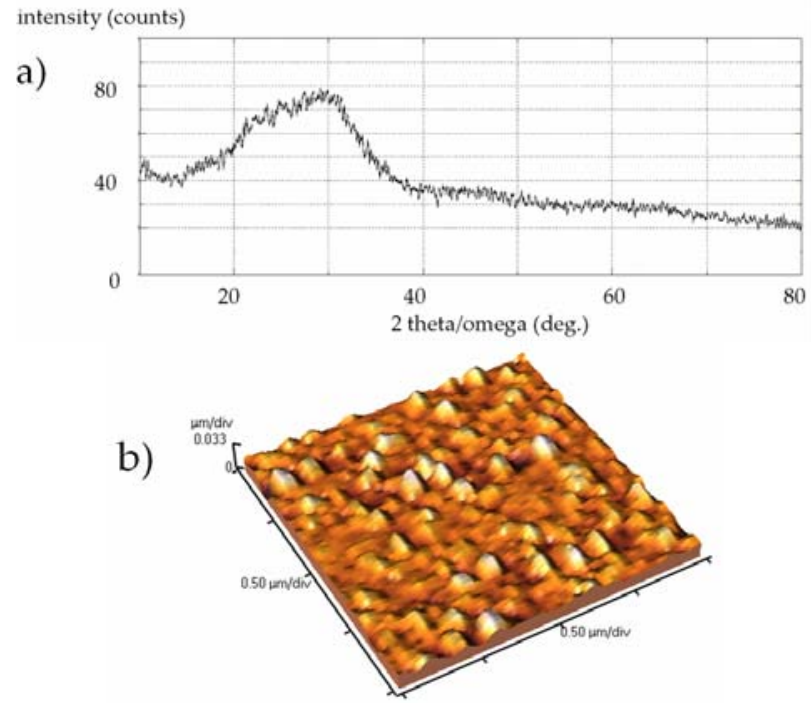

Fig. 1. X-ray diffraction picture (a) and AFM image (b) of as-deposited $\mathrm{Sb}_{20} \mathrm{Se}_{80}$ thin films. 


\section{1. $\mathrm{Sb}_{20} \mathrm{Se}_{80}$ thin films}

Thin $\mathrm{Sb}_{20} \mathrm{Se}_{80}$ films were irradiated by $\mathrm{He}-\mathrm{Ne}$ laser beam $(\lambda=633 \mathrm{~nm}$, output energy: $0.013 \mathrm{~mW}$ ). When the substrate (at RT) was illuminated with the excimer laser light for $30 \mathrm{~min}$, a local crystallization occurred on the amorphous background. The non-uniform nature of laser radiation is a source of differences in the spot morphology at the centre and in the periphery region. The surface morphology in the centre of the spot shows appearance of small hillocks with circular base and a height of $\sim 50 \mathrm{~nm}$ (Fig. 2). With increasing distance from the centre the circular structure is replaced by elongated formations (wrinkles) with a height of $\sim 20 \mathrm{~nm}$ (Fig. 3). During the etching process the general crystallized surface structure (surface morphology) remains unchanged.

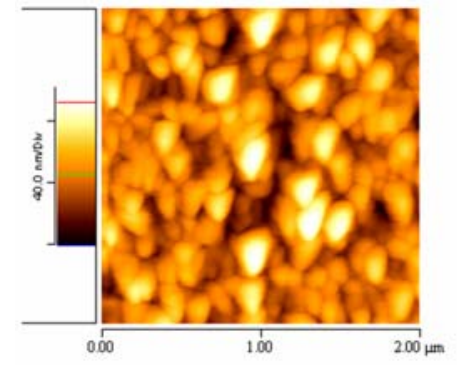

a)

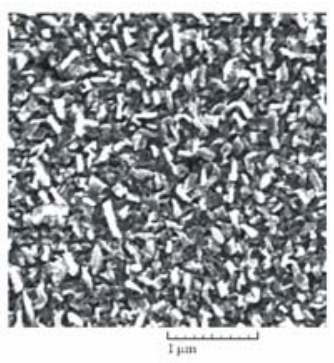

b)

Fig. 2. AFM (a) and SEM (b) surface images with hillocks at the crystallized spot centre of $\mathrm{Sb}_{20} \mathrm{Se}_{80}$ thin film.

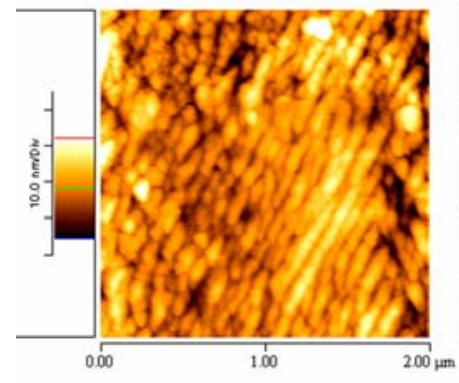

a)

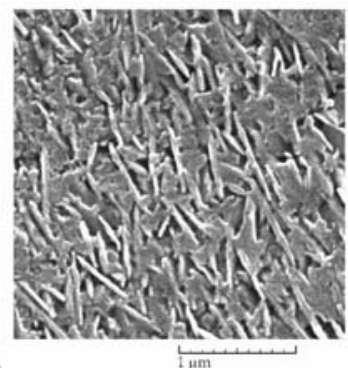

b)

Fig. 3. AFM (a) and SEM (b) surface images with wrinkles at the spot edges of $\mathrm{Sb}_{20} \mathrm{Se}_{80}$ thin film.

Changes on the sample surface under laser irradiation are shown in Fig. 4. At the beginning of irradiation, the crystalline substance with wrinkled surface is formed throughout the spot area. As exposure continues, the spot increases in size, and then in its centre a radially growing region with the circular structure (hillocks) appears, so that two concentric bands could be seen formed in the crystallized spot (60 microns in diameter, see Fig. 4c). The mentioned above dynamics of the surface change can be explained taking into account the intensity distribution within the laser beam. A Gaussian laser beam focused to a small spot spreads out rapidly as it is propagating away from the spot. Therefore, the formation of new structures is assumed to occur at the centre and then expanding radially. 


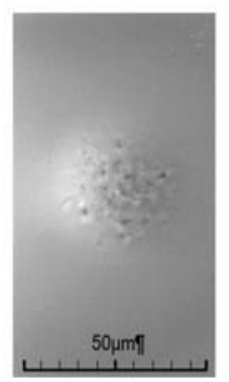

a)

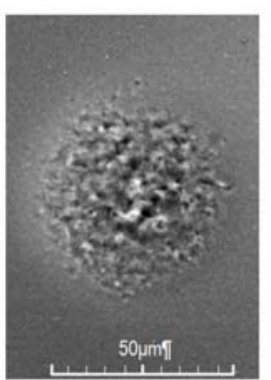

b)

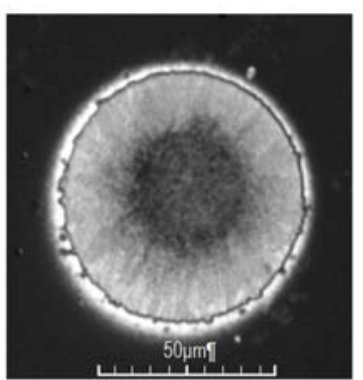

c)

Fig. 4. The SEM images of growing crystalline phase in $\mathrm{Sb}_{20} \mathrm{Se}_{80}$ thin films under laser irradiation: $5 \min (a), 10 \min (b)$ and $30 \min (c)$.

The crystallized area was analyzed using EBSD to determine whether there are crystal grains. Under close examination, the EBSD image of $\mathrm{Sb}_{20} \mathrm{Se}_{80}$ sample reveals the presence of faint lines (some of them marked). As shown in [12], lower quality EBSD images can usually be observed for particles less than $\sim 1 \mu \mathrm{m}$. Supposedly, this is a result of decrease in the intensity of electrons diffracted from small particles due to loss of electrons scattered out of the particle sides and bottom. Thus, we can assert that the polycrystalline material with grains whose size is under $100 \mathrm{~nm}$ appears as a result of laser crystallization.

The resultant thin films (locally crystallized and amorphous) were selectively etched. The amorphous portion is completely dissolved, whilst the lasercrystallized area could be considered insoluble. The amorphous background (clearly visible in Fig. 5a) disappears in the etching process, thus increasing the overall contrast seen in Fig. $5 b$.

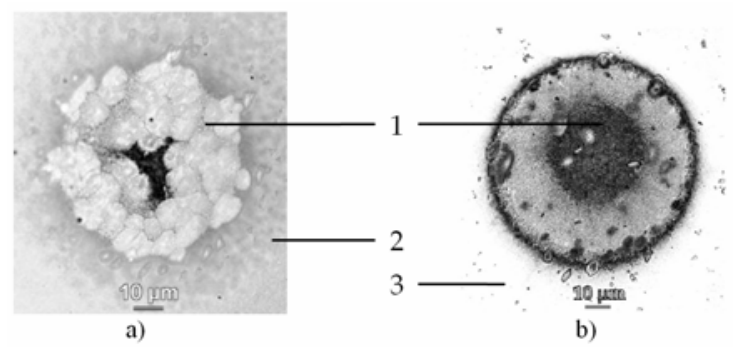

Fig. 5. The optical microscope image of $\mathrm{Sb}_{20} \mathrm{Se}_{80}$ thin film after laser crystallization $(a)$ and etching $(b) .1$ - crystalline phase, 2 - amorphous phase, 3 - substrate.

\section{2. $\mathrm{Sb}_{40} \mathrm{Se}_{60}$ thin film}

Crystallization in thin films of a stoichiometric composition significantly differs from that in $\mathrm{Sb}_{20} \mathrm{Se}_{80}$ films described above. Under laser exposure, crystallization centres initially appear in the amorphous phase at random and nonuniformly. Further irradiation leads to the nucleation and growth of crystal grains, which merge into a uniformly crystallized array (Fig. 6).

After the laser crystallization process the $\mathrm{Sb}_{40} \mathrm{Se}_{60}$ thin film surface becomes more flat and smooth compared with the amorphous region. Figure $7 a$ shows typical AFM images of the 3D surface topography for stoichiometric thin films in the crystalline phase: the small grains coalesced, resulting in a uniform surface with some additional big grains observed. 


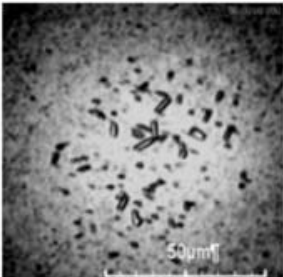

a)

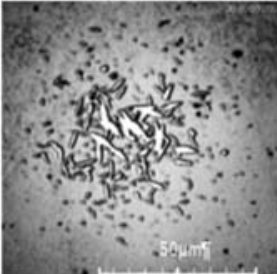

b)

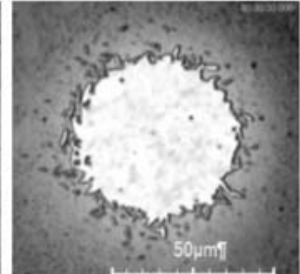

c)

Fig. 6. The optical microscope images of growing crystalline phase in $\mathrm{Sb}_{40} \mathrm{Se}_{60}$ thin films during laser irradiation: $5 \mathrm{~min}(a), 10 \mathrm{~min}(b)$ and $30 \mathrm{~min}(c)$.

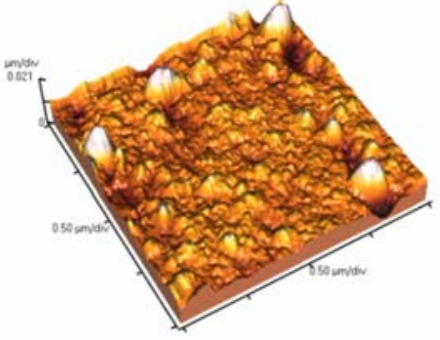

a)

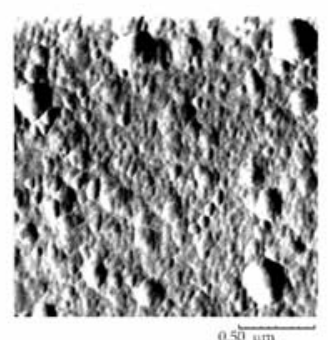

b)

Fig. 7. AFM (a) and LFM (b) images of crystallized $\mathrm{Sb}_{40} \mathrm{Se}_{60}$ thin films.

In Fig. 8 the EBSD image of $\mathrm{Sb}_{40} \mathrm{Se}_{60}$ crystallized area is displayed. Its quality (as estimated by the intensity/contrast, total number and sharpness of the Kikuchi lines) was good enough to perform phase identification analysis (PIA), with the phase of area identified as orthorhombic $\mathrm{Sb}_{40} \mathrm{Se}_{60}$.

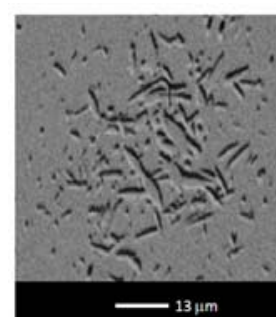

a)

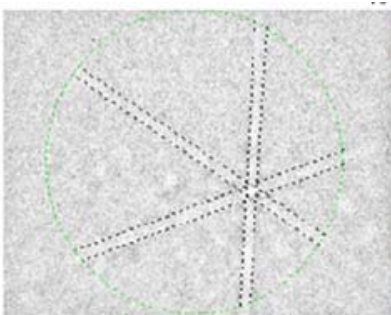

b)

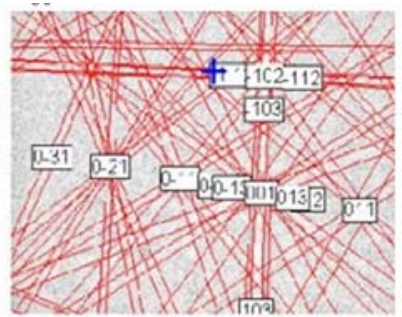

c)

Fig. 8. PIA of $\mathrm{Sb}_{40} \mathrm{Se}_{60}$ crystallized area: $a$ ) secondary electron image of the area;

b) lines in the original diffraction pattern corresponding to the peaks in the Hough transform; c) indexed EBSD pattern with simulated overlay.

The laser-treated non-etched sample has a uniform surface, without height discontinuity (Fig. 9): the space between the crystallites is suggested to be filled with amorphous $\mathrm{Sb}_{40} \mathrm{Se}_{60}$.

The laser treated $\mathrm{Sb}_{40} \mathrm{Se}_{60}$ samples (Fig. 10) demonstrate high etching selectivity: amorphous regions are completely etched, while the crystallized area cannot be etched.

In the process of etching the amorphous regions are dissolved, whilst the homogeneously crystallized areas represent structures with clearly defined edges (Fig. 10). 
a)

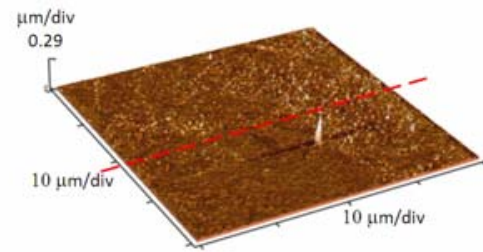

b)

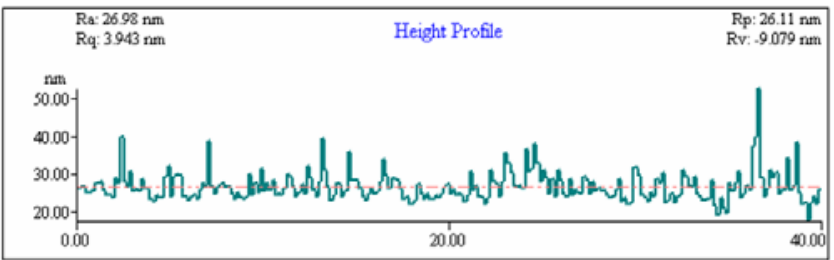

Fig. 9. AFM image of the 3D surface topography (a), and the cross-section of $\mathrm{Sb}_{20} \mathrm{Se}_{80}$ photocrystallized non-etched thin films $(b)$.

Long dashed line indicates the places where AFM cross-sections were taken.

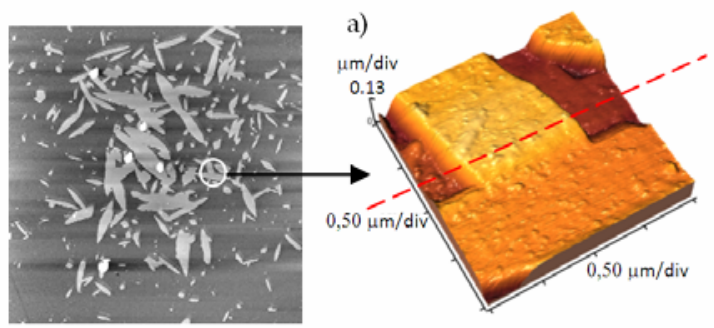

b)

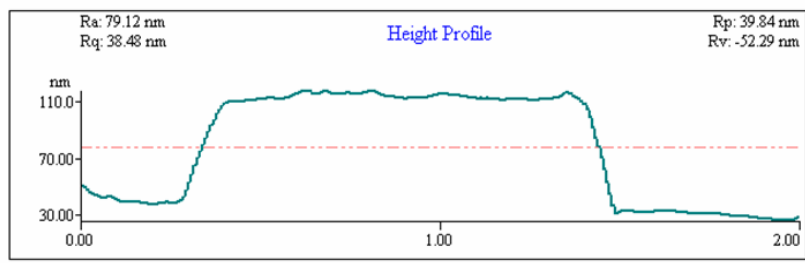

Fig. 10. AFM image of the surface topography in 3D (a) and cross-section (b) for the $\mathrm{Sb}_{40} \mathrm{Se}_{60}$ photocrystallized etched thin films.

Long dashed line indicates the location where AFM cross-sections were taken.

\section{DISCUSSION}

We have performed a quantitative microanalysis (see Table 1) with Oxford INCA starting compound for evaporation of thin films, which is given for pre- and post-stimulation by laser.

Quantitative microanalysis with an Oxford INCA

Table 1

\begin{tabular}{|l|c|c|l|c|}
\hline \multicolumn{1}{|c|}{ Spectrum } & Sb & Se & \multicolumn{1}{|c|}{ Sample } & $\begin{array}{c}\text { Starting compound for } \\
\text { evaporation }\end{array}$ \\
\hline Spectrum 1 & 20 & 80 & As-deposited, amorphous & $\mathrm{Sb}_{20} \mathrm{Se}_{80}$ \\
\hline Spectrum 2 & 30 & 70 & Crystallized & $\mathrm{Sb}_{20} \mathrm{Se}_{80}$ \\
\hline Spectrum 3 & 40 & 60 & As-deposited, amorphous & $\mathrm{Sb}_{40} \mathrm{Se}_{60}$ \\
\hline Spectrum 4 & 40 & 60 & Crystallized & $\mathrm{Sb}_{40} \mathrm{Se}_{60}$ \\
\hline
\end{tabular}


The composition of $\mathrm{Sb}_{40} \mathrm{Se}_{60}$ thin films does not change under irradiation: only $\mathrm{Sb}_{40} \mathrm{Se}_{60}$ crystallites are formed during the laser treatment (see data for spectra 3-4 in Table 1). In the exposed area the grains are formed in an amorphous matrix, with grain boundaries possessing surface energy. The smaller grains have proportionally greater surface energy than the larger ones, so it is favourable, in terms of energy, to merge the former into the larger grains. It takes time for the grains to grow in polycrystalline specimens.

However, the films with excessive selenium became on the average 10 at.\% lower in the selenium content, presumably because of its sublimation under laser treatment $[13,14]$. Therefore, marked topographic changes with thickness reduction (Fig. 11) occurred in the laser exposure area.

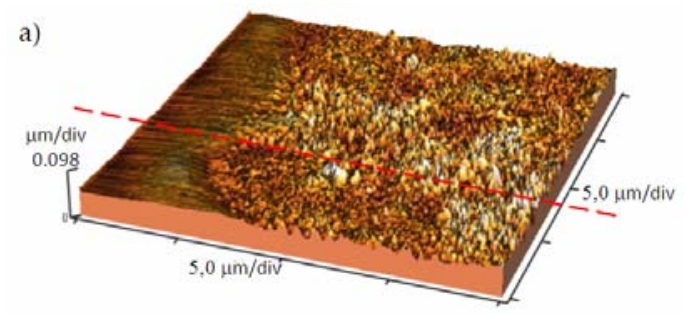

b)

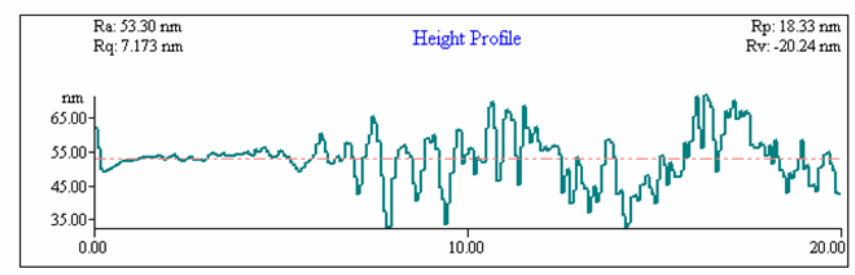

Fig. 11. AFM images of the surface topography in 3D $(a)$ and cross-sections $(b)$ for the photocrystallized non-etched spot edge area in $\mathrm{Sb}_{20} \mathrm{Se}_{80}$ thin films. Long dashed line indicates the location where AFM cross-sections were taken.

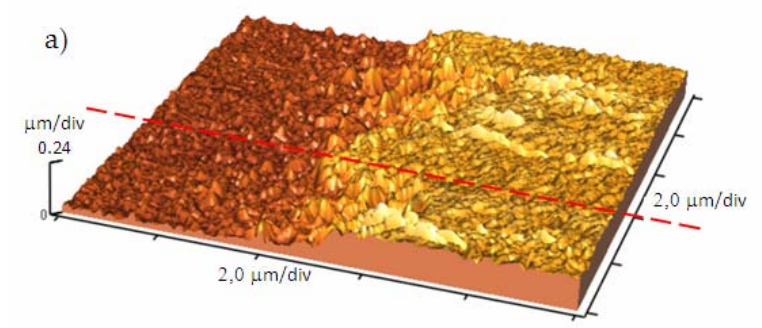

b)

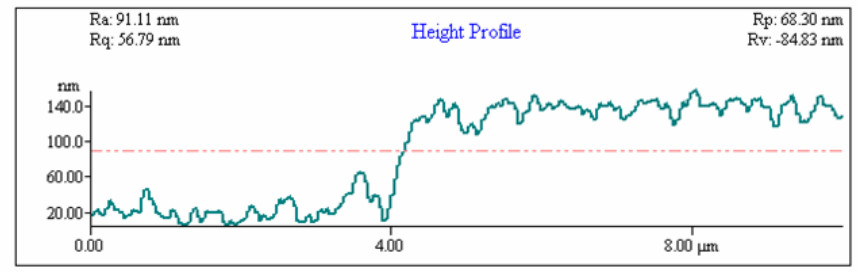

Fig. 12. AFM images of the surface topography in 3D $(a)$ and cross-sections $(b)$ for the photocrystallized etched spot edge area in $\mathrm{Sb}_{20} \mathrm{Se}_{80}$ thin films.

Long dashed line indicates the location where AFM cross-sections were taken.

Figure 12 shows the surface pattern produced by the laser treatment followed by etching in organics-based solution (e.g. amines). During laser irradiation, in 
$\mathrm{Sb}_{20} \mathrm{Se}_{80}$ thin films the $\mathrm{Se}$ and $\mathrm{Sb}_{40} \mathrm{Se}_{60}$ crystallites are formed simultaneously with the selenium sublimation process. Note that the crystallization process occurs not only in the laser- exposed area, but also around it. Therefore, the crystalline region with blurred outlines and indistinct edges is retained after etching the films.

\section{CONCLUSIONS}

The experiment with exposure of $\mathrm{Sb}_{20} \mathrm{Se}_{80}$ and $\mathrm{Sb}_{40} \mathrm{Se}_{60}$ thin films to the laser irradiation followed by etching them in organics-based solution (amines) has shown the etching selectivity between local areas of optically crystallized and amorphous $\mathrm{Sb}_{20} \mathrm{Se}_{80}$ and $\mathrm{Sb}_{40} \mathrm{Se}_{60}$ thin films with regard to the surface quality. In all cases the crystallized phase is shown to be more resistant to organic etching solution in comparison with the amorphous phase. The best surface quality has been obtained for the $\mathrm{Sb}_{40} \mathrm{Se}_{60}$ compound. Rather smooth and homogeneous surface of the samples after the photo-stimulation and after the etching process as well as fine crystalline structure makes the $\mathrm{Sb}_{40} \mathrm{Se}_{60}$ composition attractive and promising for micro- and even nano-scale lithography. Potential application of selective etching of $\mathrm{Sb}_{\mathrm{x}} \mathrm{Se}_{100-\mathrm{x}}$ could be expected in the field of making micro-optical elements, such as grids, waveguides, micro-lenses, phase-change type recording memories, etc..

\section{Acknowledgements}

This work was supported by ESF (project „Atbalsts Daugavpils Universitātes doktora studiju istenošanai" ("Support the implementation of the doctoral programme at the Daugavpils University")

Nr. 2009/0140/1DP/1.1.2.1.2/09/IPIA/VIAA/015).

The authors thank the colleagues from the Institute of Solid State Physics: J. Teteris for providing the etcher, and R. Grants, who has carried out skilful AFM experiments with patience.

\section{REFERENCES}

1. Kokenyesi, S. (2006). Amorphous chalcogenide nano-multilayers: research and development. Journal of Optoelectronics and Advanced Materials, 8(6), 2093-2096.

2. Rajpure, K.Y., \& Bhosale, C.H. (2000). Effect of Se source on properties of spray deposited $\mathrm{Sb}_{2} \mathrm{Se}_{3}$ thin films. Materials Chemistry and Physics, 62(2), 169-174. doi:10.1016/S0254-0584(99)00173-X

3. Nikam, P.S., \& Aher, H.S. (n.d.). Conduction mechanisms in co-deposited Bi-Se and $\mathrm{Sb}-\mathrm{Se}$ thin films. Indian journal of pure \& applied physics, 34(6), 393-397.

Council of Scientific \& Industrial Research. Retrieved from http://cat.inist.fr/?aModele $=$ afficheN\&cpsidt $=11028375$

4. Wood, C., Hurich, Z., \& Shaffer, J. (1972). Optical and transport properties of amorphous $\mathrm{Sb}_{2} \mathrm{Se}_{3}$. Journal of Non-Crystalline Solids, 8-10, 209-214. doi:10.1016/0022-3093(72)90138-X.

5. Dwivedi, S.K., Kushwaha, V.S., \& Kumar, A. (2008). Photo-crystallization in $\mathrm{a}-\mathrm{Se}_{1-\mathrm{x}} \mathrm{Sb}_{\mathrm{x}}$ thin films. Chalcogenide Letters, 5(9), 187-194.

Retrieved from http://www.chalcogen.infim.ro/Dwivedi-Kumar.pdf

6. Gerbreders, V., Teteris, J., Sledevskis, \& E., Bulanovs, A. (2007). Photoinduced changes of optical reflectivity in $\mathrm{As}_{2} \mathrm{~S}_{3}-\mathrm{Al}$ system. Journal of Optoelectronics and Advanced Materials, 9 (10), 3153-3156. 
7. Kurumada, M. (2003). Dynamic process of crystallization of $\mathrm{Sb} 2 \mathrm{Se} 3$ from $\mathrm{Sb}_{50} \mathrm{Se}_{50}$ amorphous film. Journal of Crystal Growth, 250 (3-4), 444-449.

doi: 10.1016/S0022-0248(02)02463-6

8. Elsayed, S. (2004). Electron beam and gamma irradiation effects on amorphous chalcogenide $\mathrm{SbSe}_{2.5}$ films. Nuclear Instruments and Methods in Physics Research Section B: Beam Interactions with Materials and Atoms, 225 (4), 535-543. doi: 10.1016/j.nimb.2004.05.033

9. Starbov, N. (1998). CW-laser-induced spherulitic recrystallization in $\mathrm{Sb}-\mathrm{Se}$ thin layer system. Proceedings of SPIE, 3404, 209-214. Spie. doi:10.1117/12.308618

10. Ko, T.Y., \& Sun, K.W. (2009). Optical and electrical properties of single $\mathrm{Sb}_{2} \mathrm{Se}_{3}$ nanorod. Journal of Luminescence, 129 (12), 1747-1749. Elsevier. doi: 10.1016/j.jlumin.2009.04.096

11. Utsugi, Y. (1993). Chemical modification for nanolithography using scanning tunneling microscopy. Nanotechnology - International Workshop on Atoms and Clusters (WAC-92); 1992 Jan 8; Atami, Japan. 1992 Oct. 161-3. Precision Engineering, 15(3), 201-201. doi:10.1016/0141-6359(93)90034-8

12. Small, J.A., \& Michael, J.R. (2001). Phase identification of individual crystalline particles by electron backscatter diffraction. Journal of Microscopy, 201(Pt 1), 59-69.

a. Retrieved from http://www.ncbi.nlm.nih.gov/pubmed/11136440.

13. Некрасов, Б.В. (1973) Основы общей химии. Т. 1, изд. 3, Москва: Химия, с. 353

14. Othmer, K. "Selenium and selenium compounds", Encyclopedia of Chemical Technology. John Wiley \& Sons, Inc., p.3. Available at:

http://www.scribd.com/doc/30122506/Selenium-and-Selenium-Compounds.

\title{
Sb-Se PLĀNĀS KĀRTIN̦AS VIRSMAS MODIFIKĀCIJA AR LĀZERU UN KODINĀŠANU
}

\author{
O. Šimane, V. Gerbreders, E. Sḷedevskis
}

\section{Kops a vilk u m}

Mūsdienu zinātniskās tehnikas attīstības līmenis l̦auj radīt materiālus un veikt to izpēti nanoizmēra līmen̄̄ (ASM, mikroanalīze). Lāzerstarojums, mijiedarbojoties ar vielu, var radīt virsmas reljefu. Arsēna halkogenīdu plānās kārtiņas tiek izmantotas virsmas reljefa iegūšanai ar selektīvas kodināšanas metodi sārmu šksīdumos. Dotajā darbā tiek apskatīta virsmas reljefa veidošanās pēc apstarošanas ar lāzerstarojumu un tam sekojošas kodināšanas. Tika pierādīta atški̧īiba starp optiski kristalizētas un amorfas $\mathrm{Sb}_{\mathrm{x}} \mathrm{Se}_{100-\mathrm{x}}$ plānās kārtin̄ās kodināšanas ātrumu, ņemot vērā virsmas kvalitāti. Visos gadījumos kristāliskā fāze ir vairāk izturīga pret kodināšanu nekā amorfā. Vislabākā virsmas kvalitāte tika iegūta $\mathrm{Sb}_{40} \mathrm{Se}_{60}$ savienojumiem. $\mathrm{Sb}_{\mathrm{x}} \mathrm{Se}_{100-\mathrm{x}}$ plānās kārtinas tiek pielietotas mikrooptiskos elementos. 